\section{THE IMPORTANCE OF PERCEIVED SERVICE QUALITY IN BANKING LOYALTY FOR LARGE BUSINESS CUSTOMERS}

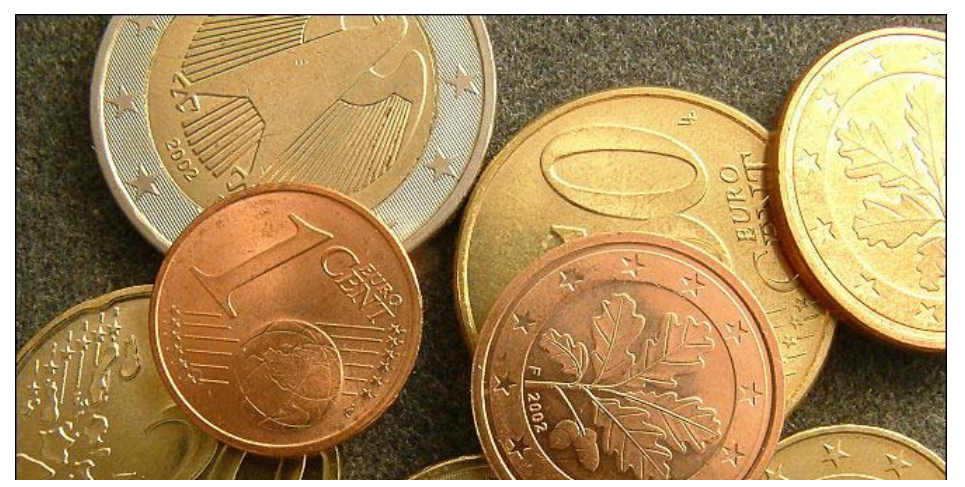

Pecvnia, Monográfico

(2010), pp. 151-164

Anabela Oliveira da Silva

Fragata ${ }^{1}$

afragata@estgl.ipv.pt

ISP Viseu (Portugal)

Pablo A. Muñoz-Gallego

pmunoz@usal.es

Universidad de Salamanca

\title{
Resumen
}

El comportamiento de las grandes empresas no financieras a la hora de seleccionar aquel que será su banco principal y el grado de fidelidad al mismo, es una cuestión a la que se ha prestado hasta ahora muy poca atención. La mayor parte de las empresas portuguesas que componen nuestra muestra, señala que trabaja con más de 5 bancos y se observa una relación positiva entre tamaño de la empresa y el número de bancos con los que opera, por lo que la competencia por el cliente aumenta, de ahí la relevancia de profundizar en la justificación de la elección del banco principal. Demostramos que el grado de fidelización al banco principal depende de la calidad percibida que se tenga del mismo, que es de carácter unidimensional, y es explicada por la variedad de productos, fiabilidad del servicio y la relación con el responsable de la sucursal que lleva su cuenta. En cambio, ni las condiciones de precio, de capacidad de respuesta de los empleados, ni el tipo de sucursal, intervienen significativamente. Este resultado puede ayudar a orientar eficazmente las estrategias de fidelización de las entidades financieras hacía sus clientes corporativos de mayor dimensión.

Palabras clave: Calidad de servicio percibida, lealtad, banca de grandes empresas, marketing financiero relacional.

\section{Abstract}

The behaviour of the large corporate banking customers when selecting the main bank and the level of their bank loyalty, are subjects that haven't been much investigated in previous studies.

Most of Portuguese large companies in our sample work with more than 5 banks and there is a positive relation between the size of the company and the number of banks used. The competition in this bank segment is fierce, so it's important to investigate the selection of the main bank.

1 Instituto Superior Politécnico de Viseu. Escola Superior de Tecnologia e Gestão de Lamego. Avda. Visconde Guedes Teixeira, 5100-074 Lamego. 
The data showed that Banking Loyalty for large corporate banking customers depends on Perceived Service Quality, which in turn is one factor construct explained by the variety of products, reliability and by the interpersonal relationship established between the decision maker of the company and the business bank manager. There is no statistical evidence to suggest that the variables Tangibles, Responsiveness and Price conditions are important to predict Perceived Service Quality for large corporate customers.

The results of his study can help banks to build a loyalty strategy towards the segment of large corporate customers.

Keywords. Perceived service quality, loyalty, large corporate banking customers, relational banking marketing.

\section{Purposes of the investigation}

In this investigation we intent to investigate the dimensions of Perceived Service Quality, for large corporate banking customers and analyse the relation with Banking Loyalty.

The corporate banking segment deserves attention because it is more valuable and more complex than the more frequently examined retail banking segment, especially in terms of frequency, value of transactions and frequency of multiple banking relationships (Tyler and Stanley, 1999).

Given the claimed benefits for business of loyal customers, it is not surprising that many businesses have invested substantial amounts in developing customer retention and cross-selling programmes in an attempt to retain customers and to obtain a higher percentage of their business.

\section{Banking loyalty for business c ustomers}

Meidan (1996) argues that the degree of loyalty in banking can be gauged by "traking customer accounts over a defined time period and noting the degree of continuity in is patronage".

Bloemer, Ruyter and Peeters (1998) defines bank loyalty as the biased (i.e. non random) behavioural response (i.e. revisit), expressed over a period of time, by some decisionmaking unit with respect to one bank out of a set of banks, which is a function of psychological (decision-making and evaluative process resulting in brand commitment).

Loyalty by business customers has been relatively neglected in research studies, perhaps due to the complexity of decisionmaking processes by organizational buyers (Lam and Burton, 2006).

While there are studies that have reviewed the extent of banks understanding of their business customers needs (Chang and $\mathrm{Ma}$, 1990; Nielsen, Terry and Tyler, 1998; Zineldin, 1995) and the relationship between customer participation and retention (Ennew and Binks, 1996), studies investigating the drivers of bank loyalty by business customers are almost completely lacking in the bank marketing literature.

Corporate banking is traditionally considered a complex function since it involves relationships between corporate firms and financial institutions (Athanassopoulos and Labroukos, 1999).

With respect to corporate banking there are differences between the nature of the relationship between a bank and its business customers depending on the size of the customers business (Butler and Durkin, 1998), as companies grow, their 
financial needs increase in complexity, as does their bargaining power in the bank customer relationship (Moriarty, Kimball and Gay, 1983).

For the banks, the large corporate market segment provides the possibility for high, volume rated margins, and it's therefore important to win lead bank status as this ensures the largest slice of the corporate banking business.

However, the larger the corporate, the grater the number of banks used (Tyler and Stanley, 1999).

This means that the competition between banks in this segment of large companies is very big and that is a great challenge for banks to provide high standards of service quality to assure customer loyalty.

\subsection{Small and medium sized corporate customers}

Lam and Burton (2006) investigated the SME banking loyalty trough a qualitative study made in Hong Kong, and found that this market is characterized by high levels of disloyalty. They also found that perceived service quality and the length of business relationship appear to have strong associations with loyalty behaviour, in terms of customer's willingness to continue to use a bank and to recommend the bank to others.

The same authors (Lam, Lo and Burton, 2005) in a later study about banking loyalty found that perceived service quality in the form of efficiency of service delivery appears to be an important driver for SME banking loyalty, the results also indicate that pricing of a loan facility has a strong impact on customer loyalty and that the relationship in the form of "guanxi" appears to have a significant negative impact on SME likelihood of switching banks. Building "guanxi" requires continuous social interactions (Tong and Yong, 1998), and thus bank managers may benefit from social interaction with the SME decision makers.

\subsection{Large corporate customers}

Turnbull and Gibbs (1989), in an empirical study focused on the banking behaviour of large corporate customers in South Africa, investigated the selection of banks and bank services and the most important factors in selection were found to be quality of service, quality of staff, the nature of relationships with managers, and price of services. Further, although most of responding companies had split banking arrangements, strong loyalty existed between organizations and their lead commercial banks.

Tyler and Stanley (1999), also investigated the large corporate expectations of service delivery from their banks, and identified some elements of operational quality service: reliability, assurance, empathy, responsiveness and proactivity.

Athanassopoulos and Labroukos (1999), examined the corporate behaviour towards financial services with a sample of the largest and profitable Greek companies, and found that some firms prefer to collaborate with the same bank for all their products while some others are not tied to one supplier and prefer a more open relationship.

\section{The influence of perceived senvice quality on banking loyalty for large corporate c ustomers}

Perceived service quality has also been found to have a positive association with customer loyalty, and it's defined as a function of expected quality (generated from market communication, image, worth-of-mouth and customer needs) and experienced quality (generated from 
functional and technical quality) (Veloutsou, Daskou and Daskou, 2004).

Perceived service quality influences the customer intentions to buy a specific brand or the portfolio of products and brands provided by a given organization. Evidence suggests that perceived quality influences consumer behaviour and intention. It is well known that evaluative judgments of service quality could significantly influence service loyalty and bank loyalty (Veloutsou, Daskou and Daskou, 2004).

Ruyter, Wetzels and Bloemer (1998), also found a positive relationship between perceived service quality and preference loyalty and price indifference loyalty.

Bahia and Nantel (2000) and Oppewal and Vriens (2000), proposed alternative models of perceived service quality in traditional banks.

Few are the studies who analysed the relations between the largest companies and their banks, but Tyler and Stanley (1999), investigated, the expectations of the largest companies to the quality of the service provided by their banks and found some elements of operational quality: Reliability (Minimal Mistakes, Efficient mistake handling, Not needing to chase, Consistency, Confidence), Assurance (Technical knowledge of bank structure), Empathy (Understanding customer needs, Trust), Responsiveness and Proactivity.

Perceived service quality influences the customer's intentions to buy a specific brand or the portfolio of products and brands provided by a given organization. Evidence suggests that perceived service quality influences consumer behaviour and intention. It is well known that evaluative judgments of service quality could significantly influence service loyalty and bank loyalty (Veloutsou, Daskou and Daskou, 2004).

Ruyter, Wetzels and Bloemer (1998) also found a positive relationship between perceived service quality and preference loyalty and price indifference loyalty. Bahia and Nantel (2000) proposed alternative models of perceived service quality in traditional banks.

Veloutsou, Daskou and Daskou (2004) also found that perceived service quality has a positive association with customer loyalty, being defined as a function of expected quality (generated from market communication, image, word of mouth and customer needs) and experienced quality (generated from functional and technical quality).

\section{Dimensions of perc eived service quality on banking}

Few were the studies that analysed the relations between the largest companies and their banks, but Tyler and Stanley (1999) investigated the expectations of the largest companies regarding the quality of the service provided by their banks and found elements of operational quality: reliability, assurance (technical knowledge of bank structure), empathy (understanding customer needs, trust), responsiveness and proactivity.

The five SERVQUAL dimensions are not universal across all services (Parasuraman, Zeithaml and Berry, 1988): Tangibles, reliability, responsiveness, assurance and empathy. Across the years the researchers have tried to improve the SERVQUAL model incorporating other construct's and measures. For this study we considered six Banking quality dimensions for the medium/large corporate customers (see Table 1 for the study measures): 


\section{Table 1}

\section{The study measures}

\begin{tabular}{|c|c|c|c|c|}
\hline & Construct & Survey measures & Variables & \\
\hline \multirow{7}{*}{ 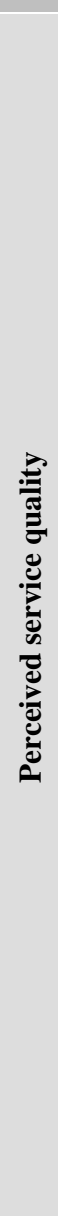 } & Tangibles & $\begin{array}{l}\text { The physical branch of the bank is } \\
\text { functional and comfortable. } \\
\text { I value the existence of a physical branch } \\
\text { of the bank near the company. }\end{array}$ & $\begin{array}{l}\text { TAN1 } \\
\text { TAN2 }\end{array}$ & $\begin{array}{l}\text { Developed for } \\
\text { this study }\end{array}$ \\
\hline & Responsiveness & $\begin{array}{l}\text { In general, I don't wait to long to solve } \\
\text { my request. }\end{array}$ & RES1 & $\begin{array}{l}\text { This item was } \\
\text { adapted from } \\
\text { SERVQUAL } \\
\text { and Tyler and } \\
\text { Stanley (1999) }\end{array}$ \\
\hline & $\begin{array}{l}\text { Product } \\
\text { variety }\end{array}$ & $\begin{array}{l}\text { The bank offers products and services } \\
\text { according to the needs of the company. } \\
\text { The bank offers a wide range of services. }\end{array}$ & $\begin{array}{l}\text { PV1 } \\
\text { PV2 }\end{array}$ & $\begin{array}{l}\text { This item was } \\
\text { adapted from } \\
\text { SERVQUAL }\end{array}$ \\
\hline & $\begin{array}{c}\text { Price } \\
\text { conditions }\end{array}$ & The bank has competitive interest rates. & Price & $\begin{array}{l}\text { Partly adapted } \\
\text { from Baumann, } \\
\text { Burton and Elliot } \\
\text { (2004) }\end{array}$ \\
\hline & Reliability & $\begin{array}{l}\text { The bank assures their services with a } \\
\text { minimum of errors. } \\
\text { I value that the bank quickly resolves the } \\
\text { existing errors. }\end{array}$ & $\begin{array}{l}\text { REL1 } \\
\text { REL2 }\end{array}$ & $\begin{array}{l}\text { This items were } \\
\text { adapted from } \\
\text { SERVQUAL, } \\
\text { and Tyler and } \\
\text { Stanley (1999) }\end{array}$ \\
\hline & $\begin{array}{l}\text { Interpersonal } \\
\text { relationships }\end{array}$ & $\begin{array}{l}\text { The bank has competent employees who } \\
\text { demonstrate the necessary banking skills. } \\
\text { The bank employees understand the } \\
\text { needs of my company. } \\
\text { The bank employees are trustworthy and } \\
\text { sincere. } \\
\text { I have a good relation with the business } \\
\text { manager of the bank. }\end{array}$ & $\begin{array}{l}\text { IPR1 } \\
\text { IPR2 } \\
\text { IPR3 } \\
\text { IPR4 }\end{array}$ & $\begin{array}{l}\text { Partly adapted } \\
\text { from Veloutsou, } \\
\text { Daskou and } \\
\text { Daskou (2004) }\end{array}$ \\
\hline & $\begin{array}{l}\text { Banking } \\
\text { loyalty }\end{array}$ & $\begin{array}{l}\text { I intend increase the utilization of this } \\
\text { bank in the future. } \\
\text { Probably we will still be working with } \\
\text { this bank in the future. }\end{array}$ & $\begin{array}{l}\text { BL1 } \\
\text { BL2 }\end{array}$ & $\begin{array}{l}\text { Developed for } \\
\text { this study }\end{array}$ \\
\hline
\end{tabular}

a) Tangibles. In a study conducted by Veloutsou, Daskou and Daskou (2004), perceived quality was determined by quality tangibles, that is, if the physical branch of the bank is functional and comfortable and if the existence of a physical branch of the bank near the company is important.

b) Responsiveness. It concerns the willingness or readiness of employees to provide service (Parasuraman, Zeithaml and Berry, 1985).

c) Product variety has also been described as a driver of perceived service quality; it concerns the variety of products and services provided by the bank and their importance to the needs of the company.

d) Price conditions. If the bank has competitive interest rates. 
e) Reliability. In many investigations, reliability was an important construct to determine perceived service quality. Parasuraman, Zeithaml and Berry (1985) defined reliability as the company's ability to perform the service right first time and honour its promises. For Tyler and Stanley (1999), this construct has four principal aspects minimal mistakes, efficient mistake handling, not needing to chase and consistent service between all bank contacts.

f) Interpersonal Relationships is the impact on business banking loyalty trough the extent of interpersonal relationships between the banks key personnel and the decision maker of the company. The personnel relationship can contribute to building durable B2B relationships witch make customers perceive the service as differentiated from other service providers (Berry, 1995).

Figure 1

\section{Proposed conceptual model}

\section{Model and hypotheses}

Based on the literature above, we propose the following hypotheses:

H1a: Tangibles positively affects e-banking service quality for corporate customers.

$\mathrm{H} 1 \mathrm{~b}$ : Responsiveness positively affects ebanking service quality for corporate customers.

H1c: Product variety positively affects ebanking service quality for corporate customers.

H1d: Price Conditions positively affects ebanking service quality for corporate customers.

H1e: Reliability positively affects e-banking service quality for corporate customers.

H1f: Interpersonal relationships positively affects e-banking service quality for corporate customers.

$\mathrm{H} 2$ : Perceived service quality has a direct positive effect on banking loyalty.

Figure 1 summarizes the research hypotheses and shows the proposed conceptual model to be estimated.

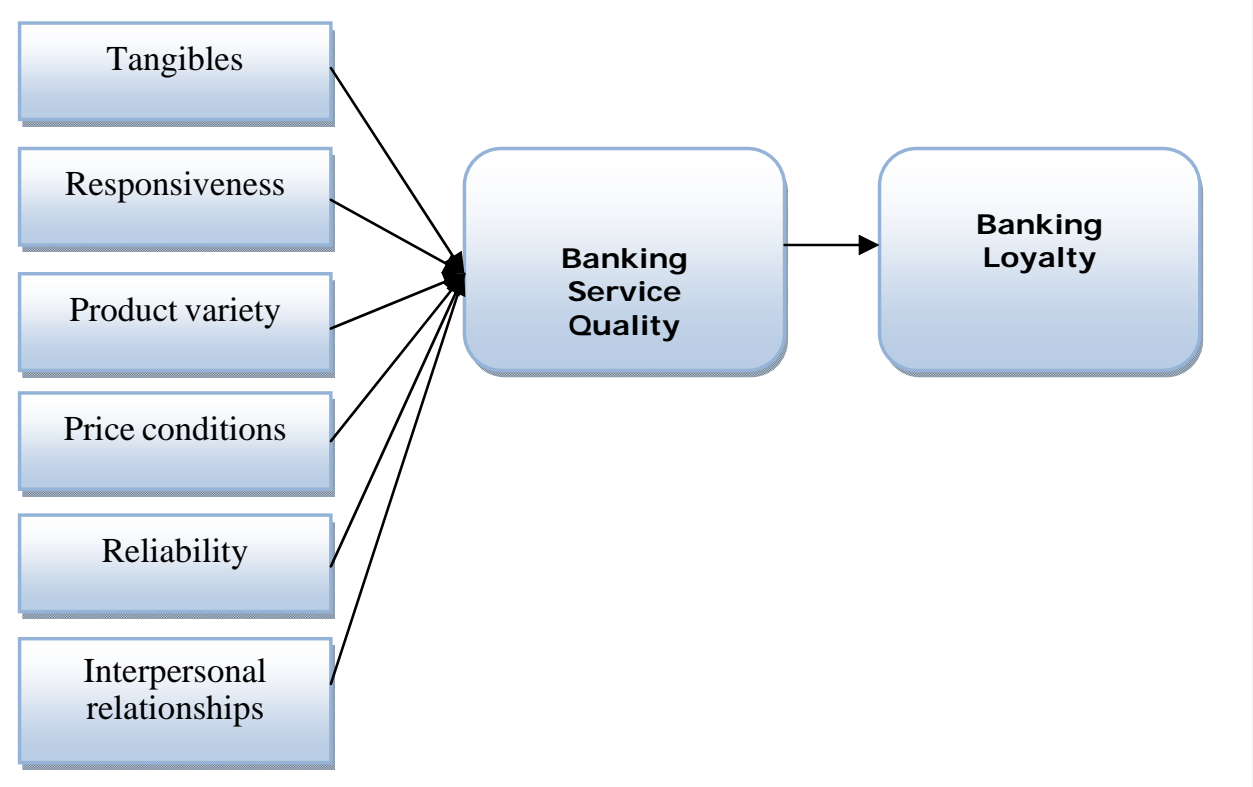




\section{Methodology and design of the investigation}

With the main purpose of testing the proposed models, it was conducted a questionnaire to medium/large corporate customers of the main Portuguese banks.

In this chapter we will describe the main objectives of the investigation, the applied methodology in the design of the questionnaire, data collection and some descriptive statistics of this data.

\section{Pre-test}

Although most of the study constructs have been previously used in many studies in other countries, the degree to which both the constructs and the concepts are transferable to Portugal were unknown.

Therefore, prior to the final study, we conducted interviews with the financial managers of five medium/large sized companies. The responses were helpful to form suitable questions for corporate customers of the Portuguese banks.

\section{Scales}

The questionnaire was structured in two parts: the first has the questions suitable to analyse the economic characteristics of the corporate respondents; and the second part has the attitudinal questions to analyse the behaviour of the companies in a context of the physical branch.

Some constructs are measured with ordinal questions others with Likert-type seven-point scale ( $1=$ Strongly Agree, $7=$ Strongly Disagree).

The type of scale used were based on relevant literature in a context of physical branch (Baumann, Burton and Elliot, 2004; Veloutsou, Daskou and Daskou, 2004; Tyler and Stanley, 1999).

\section{E-mail survey}

We conducted this study using an e-mail survey. In this mode, questionnaires traditionally are mailed to potential study participants, who complete and return them by e-mail.

Unlike personal and telephone interviews, e-mail interviews require at least broad identification of the individuals to be sampled before data collection begins.

Without such identification, and an associated e-mailing address, e-mail interview are not feasible.

Therefore previous to the final survey we conducted a previous telephone contact to 220 companies to collect an e-mail list with the identification of the financial decision maker of the company.

We used the Dun \& Bradstreet data base of the 500 biggest companies in Portugal to start collecting the e-mail contacts.

The questionnaires were then sent to the personal e-mails of the financial managers of the companies and in some cases to the general e-mail of the company, but in this case with the identification of the decision maker of the company.

The questionnaires were sent and received between August in the year of 2007 and May of 2008.

From the 220 sent questionnaires, 70 valid questionnaires were finally returned, thus yielding a $32 \%$ response rate.

\section{Sample description}

In this subsection we describe the economic characteristics of the corporate respondents. 
Table 2

Economic characteristics of the sample

\begin{tabular}{|l|l|c|c|}
\hline Variable & Category & Frequency & Valid percent \\
\hline \multirow{3}{*}{ Sector } & Industry & 31 & $44,3 \%$ \\
& Construction & 8 & $11,4 \%$ \\
& Services & 31 & $44,3 \%$ \\
\hline Number of employees & between 11 and 50 & 1 & $1,4 \%$ \\
& between 51 and 100 & 7 & $10 \%$ \\
& between 101 and 250 & 20 & $28,6 \%$ \\
\hline Annual Turnover & $>250$ & 42 & $60 \%$ \\
\hline (Thousand $€$ ) & between 2001 and 10000 & 3 & $4,3 \%$ \\
& between 10001 and 50000 & 11 & $15,7 \%$ \\
\hline \multirow{3}{*}{ Age of the company } & between 50001 and 250000 & 21 & $50 \%$ \\
& $>250000$ & 2 & $30 \%$ \\
\hline & between 2 and 5 years & 5 & $2,9 \%$ \\
\hline & between 6 and 10 years & 6 & $7,1 \%$ \\
\hline & between 11 and 15 years & 57 & $8,6 \%$ \\
\hline
\end{tabular}

In Table 2 we can see that the sample is characterized mainly by companies from the industry sector $(44,4 \%)$ and the services $(44,3 \%)$.

A major percentage of this sample is large companies with more than 250 employees
(60\%) and with an annual turnover between 50001 and 250000 thousand euro's (50\%).

The major percentage of the companies has been working with the main bank for more than 15 years $(81,4 \%)$.

Table 3

Univariate analysis of the number of banks used

\begin{tabular}{|l|c|c|c|c|}
\hline Variable & Category & Frequency & Valid percent & Other \\
\hline $\begin{array}{l}\text { Number o f banks used } \\
\text { in a context of physical }\end{array}$ & 1 & 1 & 1,4 & Mean 4,3 \\
\hline branch & 2 & 9 & 12,9 & Minimum 1 \\
& 3 & 6 & 8,6 & Maximum 5 \\
& 4 & 6 & 8,6 & Median 5 \\
& $>=5$ & 48 & 68,6 & Variance 1,3 \\
\hline
\end{tabular}

We concluded that companies have split bank arrangements, with $68,6 \%$ working with more than 5 physical bank branches. 
Figure 2

Most used bank as the first choice

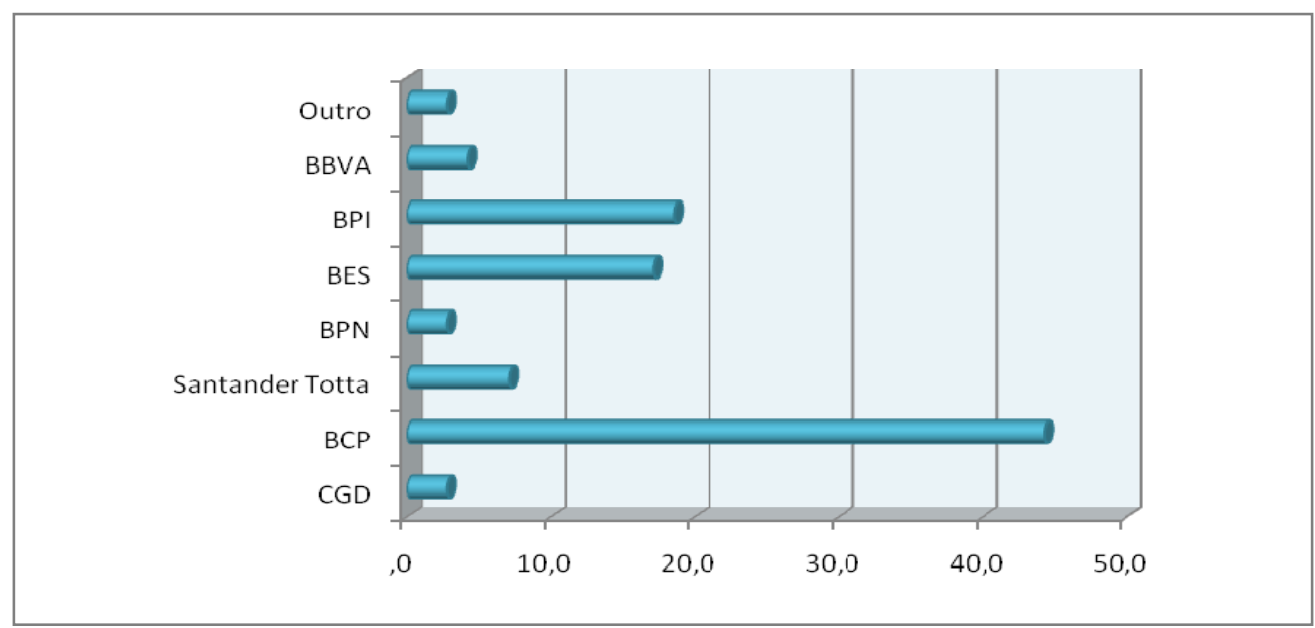

In Figure 2 we identified the most used banks in the companies as their first choice.
The data showed that the BCP is the most used bank by the companies as their first choice $(44,29 \%)$.

Figure 3

\section{Average number of banks according to firm size}

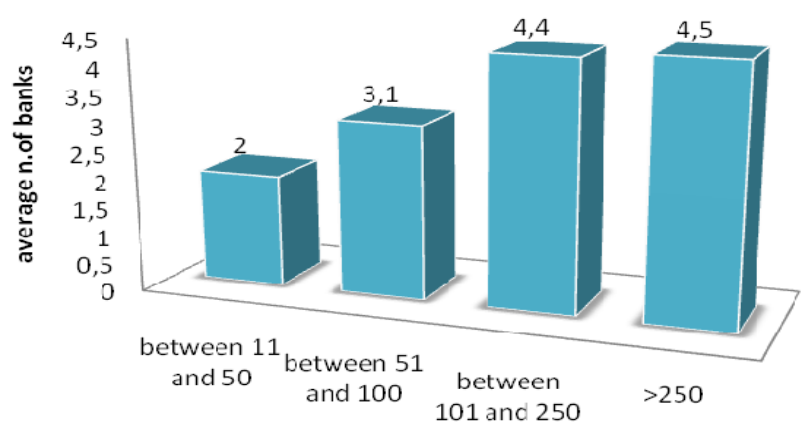

Firm size (n. of employees)

We found that the larger the size of the corporate segment, the greater the number of banks used, with the larger companies using the services of four or more banks on average, although strong loyalty exists between companies and their lead commercial bank. 


\section{Figure 4}

\section{Time working with the main bank}

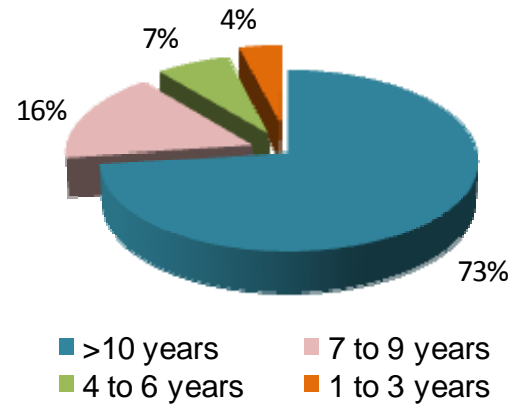

Although most of the responding companies use the services of four or more banks, strong loyalty existed between organizations and their lead commercial bank, as discussed in the previous study conducted by Turbull and Gibbs (1989).

The data showed that $73 \%$ of the companies have been working with their lead bank for more than 10 years.

\section{Findings}

We conducted the exploratory Factorial analysis with varimax rotation because we have a big number of variables in the proposed models. To achieve this goal we used the software SPSS 17.0.
We carried out a factor exploratory analysis (principal components with varimax rotation) for the latent variables. The factorial loadings were required to be higher than 0.5 points and have a significant total explained variance.

The Cronbach Alpha indicator was used to access the initial reliability of the scales, considering a minimum value of 0.7 , although this is not an absolute standard, and values below 0.7 have been deemed acceptable if the research is exploratory in nature (Hair et al., 1998).

Only one factor was estimated for each construct of perceived service quality. (See Table 4).

Table 4

\section{Exploratory Factor Analysis for the proposed model}

\begin{tabular}{|l|c|c|c|c|c|c|c|}
\hline Constructs & $\begin{array}{c}\text { Item } \\
\text { name }\end{array}$ & $\begin{array}{c}\text { Indicator } \\
\text { reliability }\end{array}$ & $\begin{array}{c}\text { Total } \\
\text { explained } \\
\text { variance }\end{array}$ & $\begin{array}{c}\text { Cronbach } \\
\text { Alpha }\end{array}$ & $\begin{array}{c}\text { Composite } \\
\text { reliability }\end{array}$ & $\begin{array}{c}\text { Variance } \\
\text { extracted }\end{array}$ & Global fit \\
\hline & PV2 & 0,74 & & & & & $X^{2}=9,4$ \\
& & & & & & \\
\hline
\end{tabular}


After the analysis of the structural model estimated, we verified the existence of offending estimates, and assessed the overall model fit with some goodness-offit measures.

Once the overall model fit was evaluated, the measurement of each construct was assessed for unidimensionality and reliability.

Although the Cronbach Alpha indicator is the most frequent test to assess reliability, some authors consider that it underestimates reliability. Consequently, the use of composite reliability and variance extracted has been suggested (Hair et al., 1998).
The commonly-used threshold value for acceptable reliability is 0.7 and for variance extracted it is 0.5 .

Construct validity was assessed considering two types of criteria: convergent and discriminatory validity.

We tested convergent validity by checking that the factor loadings of the confirmatory model were statistically significant (at the level of 0.05) and all the factor loadings exceeded 0.5 , thereby providing evidence of convergent validity of the measures.

After this analysis, we estimated the final structural model (see Figure 5), and the goodness-of-fit measures have acceptable values.

Figure 5

\section{Structural equation model}

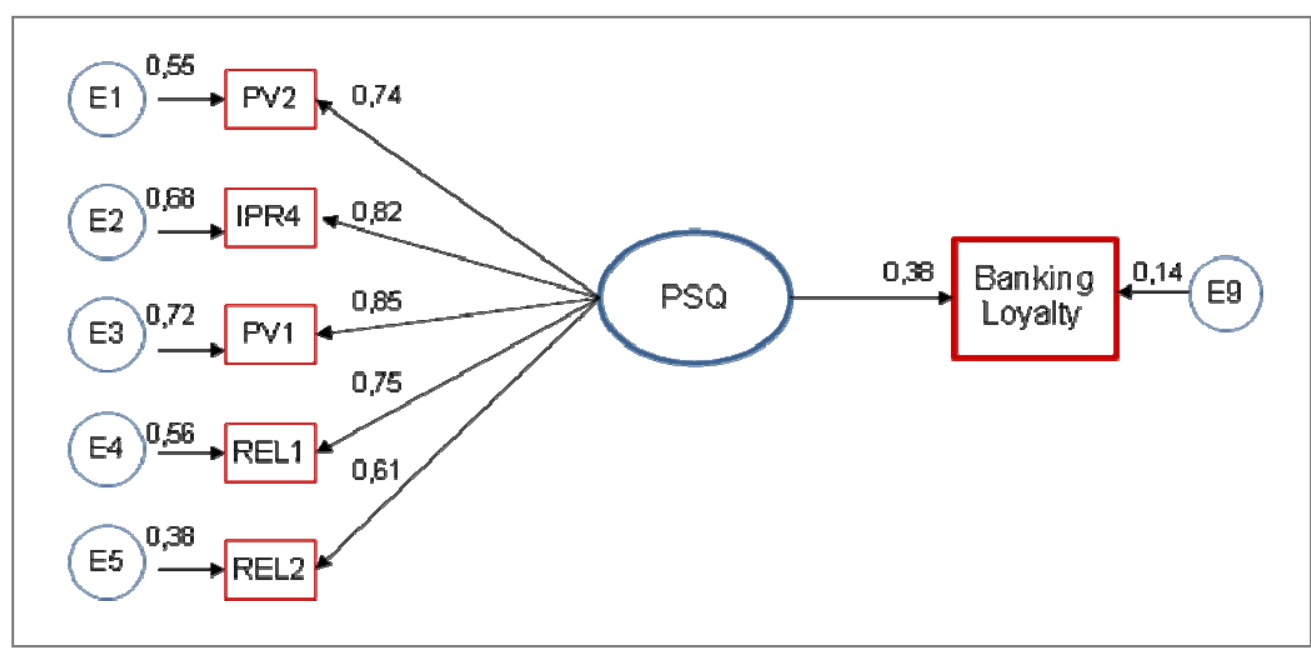

The determinant of major impact on Perceived Service Quality is PV1 and PV2 which refers to the importance of the offer of products and services according to the needs of the company, that means that there is statistical significance to affirm that the hypothesis $\mathrm{H} 1 \mathrm{C}$ is true; in second place, the variable IPR4, regarding the importance of the good relations generated between the decision-maker of the company and the bank's business manager, that means that the hypothesis $\mathrm{H} 1 \mathrm{f}$ is true; and in third place, the variable REL1 and REL 2, regarding the reliability of the services; in other words, the importance of assuring the service with the minimum of errors, that means that we can prove the hypothesis $\mathrm{H} 1 \mathrm{e}$. 


\section{Table 5}

\section{Correlations between the variables in the model}

\begin{tabular}{|c|c|c|c|c|c|c|c|}
\hline PSQ & 1,000 & & & & & & \\
\hline Loyalty & ,376 & 1,000 & & & & & \\
\hline PV1 & 847 & ,318 & 1,000 & & & & \\
\hline REL1 & ,748 & 281 & ,634 & 1,000 & & & \\
\hline REL2 & 612 & ,230 & ,519 & ,458 & 1,000 & & \\
\hline PV2 & ,741 & ,279 & 628 & ,555 & ,454 & 1,000 & \\
\hline IPR4 & ,822 & 309 & ,696 & 615 & ,503 & ,609 & 1,000 \\
\hline
\end{tabular}

There is no statistical evidence to suggest that the variables Tangibles, Responsiveness and Price conditions are important to predict Perceived Service Quality for medium/large corporate customers.

There is also statistical evidence to prove the hypothesis $\mathrm{H} 2$, with a total effect of 0,38 , that means that there is a positive direct effect of Perceived Banking Quality on Banking Loyalty, for medium/large

corporate customers.

\section{Disc ussion}

We found that the larger the size of the corporate segment, the greater the number of banks used, with the larger companies using the services of four or more banks on average, although strong loyalty exists between companies and their lead commercial bank.

The data also showed that BCP is the most-used bank by the companies as their first choice.

This study also suggests that perceived service quality -specifically three dimensions (the importance of the offer of products and services according to the needs of the company, the good relations generated between the decision-maker of the company and the bank's business manager, and assuring the service with the minimum of errors)- appears to be the primary driver of bank loyalty in this segment.

The first dimension was discussed by other authors as influencing the bank-company relationship and the choice of the main bank by customers. Lam and Burton (2006), for instance, stated that the ability to understand and accommodate specific customer needs appeared to be important in influencing the corporate choice of banks. They also found that for companies who are loyal to only one bank, the key determinant for remaining with that bank was the ability to accommodate their needs.

The second dimension emphasizes the importance of interpersonal relationships in maintaining corporate customers. For example, changes in bank policy and/or bank managers were identified as having caused some customers to change banks. This suggests that bank strategy may need to pay more attention to the potential negative effects on customer behaviour of any change in staffing or lending policy (Lam and Burton, 2006).

The third dimension of perceived service quality is of great importance for the decision-maker at the company. Corporate customers expect transactions to be made with the minimum of errors, mainly because an error in certain transactions can seriously compromise the company. 
In the study conducted by Tyler and Stanley (1999), reliability was an important driver for operational quality service. They evidenced that even if mistakes were made, it was expected that the bank would handle them swiftly and efficiently.

In contrast, the importance of the quality of the physical branch of the bank is the least relevant to determining bank loyalty by corporate customers. This might indicate that the physical evidence of the service has less importance than in the past for informing a customer's views on service quality, satisfaction and loyalty (Veloutsou, Daskou and Daskou, 2004).

\section{References}

Anderson, R.E. and Srinivasan, S.S. (2003). "E-satisfaction and e-loyalty: A contingency framework". Psychology and Marketing, vol. 20, n. 2, pp. 123-138.

Athanassopoulos, A.D. and Labroukos, N.S. (1999). "Corporate customer behaviour towards financial services: Empirical results from emerging market of Greece". International Journal of Bank Marketing, vol. 17, n. 6, pp. 274-285.

Bahia, K. and Nantel, J. (2000). "A reliable and valid measurement scale for perceived service quality of banks". International Journal of Bank Marketing, vol. 18, n. 2, pp. 84-91.

Baumann, C.; Burton, S. and Elliot, G. (2004). "Determinants of customer loyalty and share of wallet in retail banking". Journal of Financial Services Marketing, vol. 9, pp. 231-248.

Berry, L. (1995). "Relationship marketing of services-growing interest, emerging perspectives". Journal of the Academy of Marketing Science, vol. 23 n. 4, pp.236245.

Bloemer, J.; Ruyter, K. and Peeters, P. (1998). "Investigating the drivers of bank loyalty: The complex relationship between image, service quality and satisfaction". International Journal of Bank Marketing, vol. 16, n. 7, pp. 276-286.

Butler, P. and Durkin, M. (1998). "Relationship intermediaries: Business advisers in the small firm-bank relationship". International Journal of Bank Marketing, vol. 16, n. 1, pp. 32-38.

Chang, A. and Ma, V. (1990). "Corporate banking behaviour: A survey in Hong Kong". International Journal of Bank Marketing, vol. 8, n. 2, pp. 25-31.

Ennew, C.T. and Binks, M.R. (1996). "The impact of service quality and service characteristics on customer retention: small business and their banks in the U.K.". British Journal of Management, vol. 7, n. 3, pp. 219-230.

Hair, J.F.; Anderson, R.L.; Tatham, R.L. and Black, W.C. (1998). Multivariate data analysis. $5^{\text {th }}$ ed. Upper Saddle River (Nueva Jersey): Prentice Hall.

Jun, M. and Cai, S. (2001). "The key determinants of Internet banking service quality: A content analisys". International Journal of Bank Marketing, vol. 19, n. 7, pp. 276291.

Lam, R.; Lo, H.P. and Burton, S. (2005). “Investigating the drivers of SME's banking loyalty in Hong Kong", proceedings of the Australian and New Zealand Marketing Academy (ANZMAC) 2005 Conference, Perth, Australia, pp. 172-180. 
Lam, R. and Burton, S. (2006). "SME banking loyalty: A qualitative study in Hong Kong”. International Journal of Bank Marketing, vol. 24, n. 1, pp. 37-52.

Liao, Z. and Cheung, M. (2002). "Internet-based e-banking and consumer attitudes: An empirical study". Information \& Management, vol. 39, n. 4, pp. 283-295.

Meidan, A. (1996). Marketing financial services. Houndmills (Basingstoke): MacMillan.

Morgan, R. and Hunt, S. (1994). "The commitment-trust theory of relationship marketing”. Journal of Marketing, vol. 58, n. 3, pp. 20-38.

Moriarty, R.; Kimball, R. and Gay, J. (1983). "The management of corporate banking relationships”. Sloan Management Review, vol. 24, n. 3, pp. 3-15.

Nielsen, J.F.; Terry, C. and Tyler, R.M. (1998). "Business banking in Australia: A comparison of expectations". International Journal of Bank Marketing, vol. 16, n. 6, pp. 253-263.

Oppewal, H. and Vriens, M. (2000). "Measuring perceived service quality using integrated conjoint experiments". International Journal of Bank Marketing, vol. 18, n. 4, pp. 154-169.

Parasuraman, A.; Zeithaml, V. and Berry, I. (1985). "A conceptual model of service quality and its implications fo future research". Journal of Marketing, vol. 49, n. 4, pp. 41-50.

Parasuraman, A.; Zeithaml, V. and Berry, I. (1988). "SERVQUAL: A multiple-item scale for measuring consumer perceptions of service quality". Journal of Retailing, vol. 64, n. 1, pp. 12-40.

Ruyter, K.; Wetzels, M. and Bloemer, J. (1998). “On the relationship between perceived service quality, service loyalty and switching costs". International Journal of Service Industry Management, vol. 9, n. 5, pp. 436-453.

Tong, C. and Yong, P. (1998). "Guanxi bases, Xinyong and Chinese business networks". The British Journal of Sociology, vol. 49, n. 1, pp. 75-96.

Turnbull, P. and Gibbs, M. (1989). "The selection of banks and banking services among corporate customers in South Africa". International Journal of Bank Marketing, vol.7, n. 5, pp. 36-39.

Tyler, K. and Stanley, E. (1999). "Marketing financial services to business: A critical review and research agenda". International Journal of Bank Marketing, vol. 17, n. 3, pp. 98-115.

Veloutsou, C.; Daskou, S. and Daskou, A. (2004). "Are the determinants of bank loyalty brand specific?". Journal of Financial Services Marketing, vol. 9, n. 2, pp. 113-125.

Zineldin, M. (1995). "Bank-company interactions and relationships: Some empirical evidence". International Journal of Bank Marketing, vol. 13, n. 2, pp. 30-40.

\section{Images}

Page 151: http://lasorcitroen.files.wordpress.com/2008/07/euros.jpg 